Article

\title{
Cellulolytic Bacteria Associated with the Gut of Dendroctonus armandi Larvae (Coleoptera: Curculionidae: Scolytinae)
}

\author{
Xia Hu, Jiamin Yu, Chunyan Wang and Hui Chen * \\ College of Forestry, Northwest A\&F University, Yangling 712100, Shaanxi, China; \\ E-Mails: lake-autumn@163.com (X.H.); yjm407@nwsuaf.edu.cn (J.Y.); chunyan@nwsuaf.edu.cn (C.W.) \\ * Author to whom correspondence should be addressed; E-Mail: chenhui@nwsuaf.edu.cn; \\ Tel./Fax: +86-29-8708-2083.
}

Received: 13 January 2014; in revised form: 26 February 2014 / Accepted: 17 March 2014 /

Published: 21 March 2014

\begin{abstract}
The object of this study was to investigate the cellulolytic bacterial community in the intestine of the Chinese white pine beetle (Dendroctonus armandi) larvae. A total of 91 cellulolytic bacteria were isolated and assigned to 11 genotypes using amplified ribosomal DNA restriction analysis (ARDRA). Partial 16S rDNA sequence analysis and morphological tests were used to assign the 11 representative isolates. The results showed that the isolates belonged to $\alpha$-Proteobacteria, $\gamma$-Proteobacteria and Firmicutes. Members of $\gamma$-Proteobacteria were the most frequently represented species and accounted for $73.6 \%$ of all the cellulolytic bacteria. The majority of cellulolytic bacteria in $D$. armandi larva gut were identified as Serratia and accounted for 49.5\%, followed by Pseudomonas, which accounted for $22 \%$. In addition, members of Bacillus, Brevundimonas, Paenibacillus, Pseudoxanthomonas, Methylobacterium and Sphingomonas were found in the D. armandi larva gut. Brevundimonas kwangchunensis, Brevundimonas vesicularis, Methylobacterium populi and Pseudoxanthomonas mexicana were reported to be cellulolytic for the first time in this study. Information generated from the present study might contribute towards understanding the relationship between bark beetle and its gut flora.
\end{abstract}

Keywords: gut microflora; ARDRA; Dendroctonus armandi; cellulase; bark beetle 


\section{Introduction}

As the primary structural material of plant cell walls, cellulose is a complex carbohydrate polymer of glucose residues that are connected by $\beta-1,4$ linkages [1]. In nature, lignocellulose is degraded by hydrolytic and oxidative enzymes that are produced mainly by fungi and bacteria which are able to synergistically degrade cellulose, hemicellulose and lignin [2]. Some insects, such as termites, beetles, wood-feeding roaches and leaf-cutting ants, can use lignocellulosic substrates as their main food source and are highly efficient at degrading cellulose to glucose as an energy source [3]. The gut systems of these insects are diverse, highly adapted and considered to be highly efficient natural bioreactors [3]. Furthermore, the intestinal microorganisms of these lignocellulose-degrading insects are considered to be essential for cellulose digestion [4]. Biodegradation of cellulose and hemicellulose, which are the recalcitrant components of the plant cell wall, by the cellulolytic activity of endosymbionts in the digestive tract of insects such as termites has been well studied [5]. However, the role of the symbiotic intestinal microbes of bark beetles, which is one of the most important woody plant-feeding insects, is unclear.

Bark beetles, especially Dendroctonus species, are considered to be serious pests of coniferous forests [6]. The Chinese white pine beetle (Dendroctonus armandi Tsai and Li), which is an important pest in the Qinling and Bashan Mountains in Northern China, can kill living Pinus armandi and has brought about huge economic losses; therefore, it represents a major disturbance factor for the ecosystem [7]. The larvae of $D$. armandi bore into the bark of $P$. armandi and feed on its nutrient-poor phloem substrates. Symbiotic microbes provide nutritional supplements that benefit their hosts [8], and the intestinal bacteria in the hindgut of bark beetles, such as D. frontalis and D. rhizophagus, might be responsible for the cellulose degradation $[9,10]$.

Our previous work has investigated the gut bacteria community of $D$. armandi using uncultured methods [11], Because little is known regarding the potential roles that gut bacteria play in its cellulose digestion, this work attempted to investigate the cellulose-degrading bacterial community in the gut of D. armandi larvae using amplified ribosomal DNA restriction analysis (ARDRA), which could specifically evaluate the nutritional contributions of gut bacteria to the Chinese white pine beetle.

\section{Experimental Section}

\subsection{Insect Collection and Dissection}

D. armandi larvae were collected from the bark of infested $P$. armandi at the Huoditang Experimental Forest Station of Northwest A\&F University, which is located on the southern slope of the middle Qinling Mountains $\left(33^{\circ} 18^{\prime}-33^{\circ} 28^{\prime} \mathrm{N}, 108^{\circ} 21^{\prime}-108^{\circ} 39^{\prime} \mathrm{E}\right)$, Shaanxi, CN, in August 2012. All samples were obtained manually and directly from galleries of infested pine trees using fine forceps and then transported to the laboratory in sterile vials containing sterile moist paper, where they were left for $48 \mathrm{~h}$ to allow the indigested food to leave the intestinal canal. Nine healthy larvae were sterilized by submersion in $70 \%$ ethanol for $3 \mathrm{~min}$ and then rinsed in sterile water twice prior to dissection. Specimens were dissected under a stereomicroscope using insect pins to obtain the hindguts and then transferred to $1.5-\mathrm{mL}$ microcentrifuge tubes containing $0.5 \mathrm{~mL}$ of PBS. 


\subsection{Isolation and Counting of Cellulolytic Microorganisms}

For viable counts, three tubes, each with an individual gut, were squeezed several times using a plastic pestle, $1 \mathrm{~mL}$ of PBS was added, and the sample was centrifuged at $4000 \mathrm{rpm}$ at $4{ }^{\circ} \mathrm{C}$ for $10 \mathrm{~s}$ to separate the microbial cells from the gut wall. The bacterial suspension was serially diluted ten-fold (to $10^{-9}$ ). One hundred microliters of each dilution was spread on plates containing solid medium 1 . Only the colonies encircled by a clear zone after Congo red $(1 \mathrm{mg} / \mathrm{mL})$ staining were counted. The dilution series was also used for enrichment in $50-\mathrm{mL}$ flasks containing $10 \mathrm{~mL}$ of medium 1 [peptone, $5 \mathrm{~g} / \mathrm{L}$; yeast extract, $0.1 \mathrm{~g} / \mathrm{L} ; \mathrm{K}_{2} \mathrm{HPO}_{4}, 1 \mathrm{~g} / \mathrm{L} ; \mathrm{MgSO}_{4} \cdot 7 \mathrm{H}_{2} \mathrm{O}, 0.2 \mathrm{~g} / \mathrm{L}$; carboxymethyl cellulose sodium salt (CMC, low viscosity; Sigma, St. Louis, MO, USA), $10 \mathrm{~g} / \mathrm{L} ; \mathrm{Na}_{2} \mathrm{CO}_{3}, 10 \mathrm{~g} / \mathrm{L}$ (sterilized separately); $\mathrm{pH} 7.0]$. The flasks were incubated aerobically and shaken at $180 \mathrm{rpm}$ at $28{ }^{\circ} \mathrm{C}$ in the dark. After 1 month, the cellulolytic colonies were counted as described above.

To isolate cellulolytic bacteria, methods and media were adapted from Delalibera et al. [9]. In brief, the supernatant (containing bacteria) of a larval gut was transferred to a 50-mL flask containing $15 \mathrm{~mL}$ medium 2a, $5 \mathrm{~g} / \mathrm{L}$ filter paper strips (Whatman), $40 \mathrm{mg} / \mathrm{L}$ Bacto yeast extract (Becton Dickinson, Sparks, MD), $100 \mathrm{mg} / \mathrm{L}$ malt extract (Becton Dickinson) and $2 \mathrm{~g} / \mathrm{L} \mathrm{CaCO}_{3}, \mathrm{pH} 7.0$ or medium $2 \mathrm{~b}$, which contained $5 \mathrm{~g} / \mathrm{L} \mathrm{CMC}, 30 \mathrm{mg} / \mathrm{L}$ yeast extract, $100 \mathrm{mg} / \mathrm{L}$ malt extract, and $2 \mathrm{~g} / \mathrm{L}$ $\mathrm{CaCO}_{3}, \mathrm{pH}$ 7.0. Liquid incubation was performed as described above. To confirm crystalline cellulose, microbes with carboxymethylcellulase activity were inoculated in medium 2c, which contained $5 \mathrm{~g} / \mathrm{L}$ phosphoric- acid-swollen Avicel (PH105), $1.9 \mathrm{~g} / \mathrm{L} \mathrm{K}_{2} \mathrm{HPO}_{3}, 0.94 \mathrm{~g} / \mathrm{L} \mathrm{KH}_{2} \mathrm{PO}_{3}, 1.68 \mathrm{~g} / \mathrm{L} \mathrm{NaHCO}_{3}$, $1.6 \mathrm{~g} / \mathrm{L} \mathrm{KCl}, 1.43 \mathrm{~g} / \mathrm{L} \mathrm{NaCl}, 0.15 \mathrm{~g} / \mathrm{L} \mathrm{NH} \mathrm{NCl}_{4}, 0.037 \mathrm{~g} / \mathrm{L} 7 \mathrm{H}_{2} \mathrm{O} \cdot \mathrm{MgSO}_{4}, 0.017 \mathrm{~g} / \mathrm{L} \mathrm{CaCl} \mathrm{Cl}_{2} \cdot 2 \mathrm{H}_{2} \mathrm{O}$ and $0.1 \mathrm{~g} / \mathrm{L}$ yeast extract, $\mathrm{pH}$ 7.0. After 7 days of enrichment, $100 \mu \mathrm{L}$ serial dilutions of the cultures were transferred to solid medium 3 (5 g/L CMC, $0.2 \mathrm{~g} / \mathrm{L}$ yeast extract, and $12 \mathrm{~g} / \mathrm{L}$ agar, $\mathrm{pH} 7.0$ ). All experiments were performed in triplicate.

\subsection{CMC Assay}

Microorganisms on solid media $2 \mathrm{a}$ and media $2 \mathrm{~b}$ were tested for their ability to degrade CMC by covering the Petri dishes with Congo red dye [12]. CMC degradation was indicated by a clear zone surrounding the colonies.

\subsection{ARDRA}

Bacterial DNA was extracted using the E.Z.N.A. bacteria DNA kit (Omega Biotech, Doraville, GA, USA) according to the manufacturer's directions. The 16S rRNA bacterial genes were amplified using primers fD1 and rP1 [13], and the amplified DNA was for restriction digestion.

Restriction of $5 \mu \mathrm{L}$ PCR products was carried out for $2 \mathrm{~h}$ at $37{ }^{\circ} \mathrm{C}$ using $1.5 \mathrm{U}$ of each of the following restriction enzymes: HhaI, $A f a \mathrm{I}$ and MspI (TaKaRa Biotechnology, Dalian, China). Aliquots $(5 \mu \mathrm{L})$ of each digested product were analyzed using gel electrophoresis in an $8 \%$ nondenaturing acrylamide gel (acrylamide: $N, N^{\prime}$-methylenebisacrylamide, 29:1) [14] by staining with ethidium bromide solution and photographed under UV light using the Gel Doc ${ }^{\mathrm{TM}} \mathrm{XR}$ System (Bio-Rad, Hercules, CA, USA). For each distinct ARDRA group, one bacterial isolate was selected for sequencing and morphological characterization. 


\subsection{Molecular and Phylogenetic Analysis}

Sequences were matched to sequences in the RDP II database [15], and BLASTed to the NCBI database [16] to select reliable, highly similar sequences to determine the classification status of these bacteria. All sequences were deposited into the NCBI database with accession numbers (KF501473-KF501484). The phylogenetic relationships of these intestinal bacteria were analyzed using molecular phylogeny. The sequences were aligned using MUSCLE [17], which is available in MEGA 5, and a Neighbor-joining tree was constructed [18]. To calculate the support for each clade, bootstrap analysis was performed with 1000 replications.

\subsection{Operational Taxonomic Units (OTU)}

Sequences in the phylogenetic tree were formatted as FASTA files and used to construct distance matrices for gene fragment sequences using MOTHUR 1.29.0. The distance matrices were used as the input files to define the OTU on the basis of a similarity distance cutoff of 0.03 ; this distance generally corresponded to a species [19]. Sequences belonging to the same OTUs ${ }_{0.03}$ cluster were circumscribed with brackets in the phylogenic trees and were identified using I-VIII for the purpose of clarity.

\subsection{Morphological and Physiological Characteristic Tests}

For each ARDRA group, one representative isolate was selected for microscopic examination. Cell morphology was examined using light microscopy (Model ZS2-ILST; Olympus, Tokyo, Japan). Gram staining was carried out using the standard Gram reaction combined with the KOH lysis test [20]. Flagella were stained according to the method of Leifsson [21].

\section{Results and Discussion}

Viable counting demonstrated that the population density of the cellulolytic bacteria in $D$. armandi larvae was $1.1 \pm 0.46 \times 10^{2} \mathrm{CFU} /$ gut, which was lower than that of other beetles, such as Saperda vestita $\left(2.4 \times 10^{5}\right.$ to $3.57 \times 10^{6} \mathrm{CFU} /$ gut $)$ [9] and D. rhizophagus $\left(2.3 \pm 0.43 \times 10^{3} \mathrm{CFU} /\right.$ gut $)$ [10]. After one month of enrichment, the population density of the bacteria with CMCase activities was $1.5 \pm 0.4 \times 10^{4} \mathrm{CFU} /$ gut, which was also lower than that of other insects, such as Holotrichia parallela $\left(1.14 \pm 0.13 \times 10^{8} \mathrm{CFU} /\right.$ gut $)$ and Pachnoda marginata $\left(2.5 \pm 1.1 \times 10^{8} \mathrm{CFU} / \mathrm{mLgut}\right)[4,22]$. These findings support similar findings from our earlier study [11] that suggested that the bacterial community in $D$. armandi larvae has low abundance and complexity compared to those of other beetles.

Eleven cellulolytic bacteria that were directly from the gut content and had the same colony characters were detected on the dilution plates, while, after one-month incubation, 91 cellulolytic bacteria were isolated. Of these, 32 were obtained using the enriching method on filter paper (2a), and 59 isolates were obtained by direct plating on CMC medium (2b). These isolates produced variable zones of CMC clearance (Figure 1) with a ratio of the clearance zone diameter ( $\mathrm{mm}$ ) to the colony diameter ranging from 1.0 to 6.6. Eleven direct isolates and 91 enrichment isolates were assigned to 11 genotypes using ARDRA. Combining the results of molecular and phylogenetic analysis (Figure 2) and morphological identification, 11 direct isolates belonged to Serratia of Proteobacteria, and the 
genotype was the same as the representative stain B (Table 1). The gut associated cellulolytic enrichment bacteria in D. armandi larvae were clustered into 2 phyla (Proteobacteria and Firmicutes), and represented 8 different genera (Figure 2). The cellulolytic bacterial communities were represented by members of the Proteobacteria (82.4\%) and Firmicutes (17.6\%) phyla (Figure 3). On the generic level, Serratia (49.5\%), Pseudomonas (22\%) and Bacillus (13.2\%) were the dominant identified genera, with 45, 20 and 12 isolates, respectively. The remaining bacterial isolates composed 15.4\% Brevundimonas (5.5\%), Paenibacillus (4.4\%), Pseudoxanthomonas (2.2\%), Methylobacterium (2.2\%) and Sphingomonas (1.1\%).

Figure 1. Screening for cellulolytic bacteria by covering the Petri dishes with Congo red dye. A zone of clearance surrounding a colony is indicative of carboxymethyl cellulose (CMC) hydrolysis by secreted CMCase.

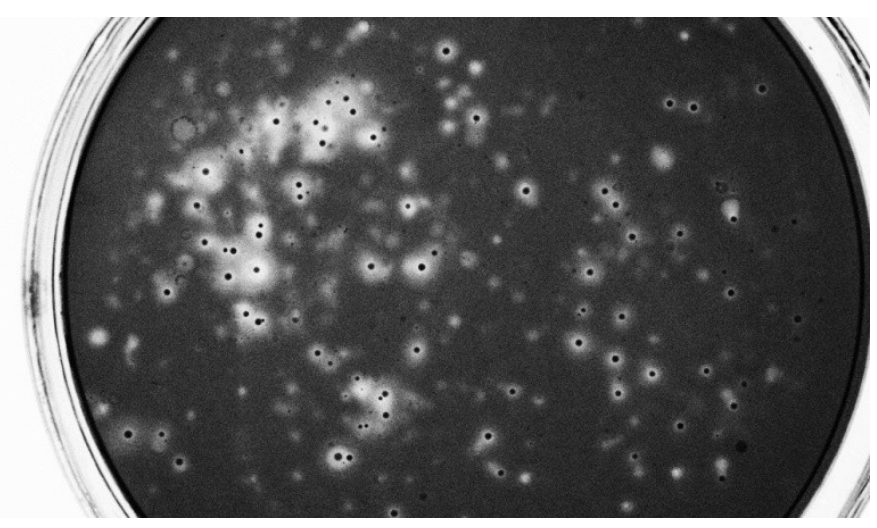

Figure 2. Neighbor-joining phylogenetic tree of 16S rRNA gene fragments of Dendroctonus armandi gut cellulolytic bacteria (enrichment isolates) (model: Tajima-Nei+G).

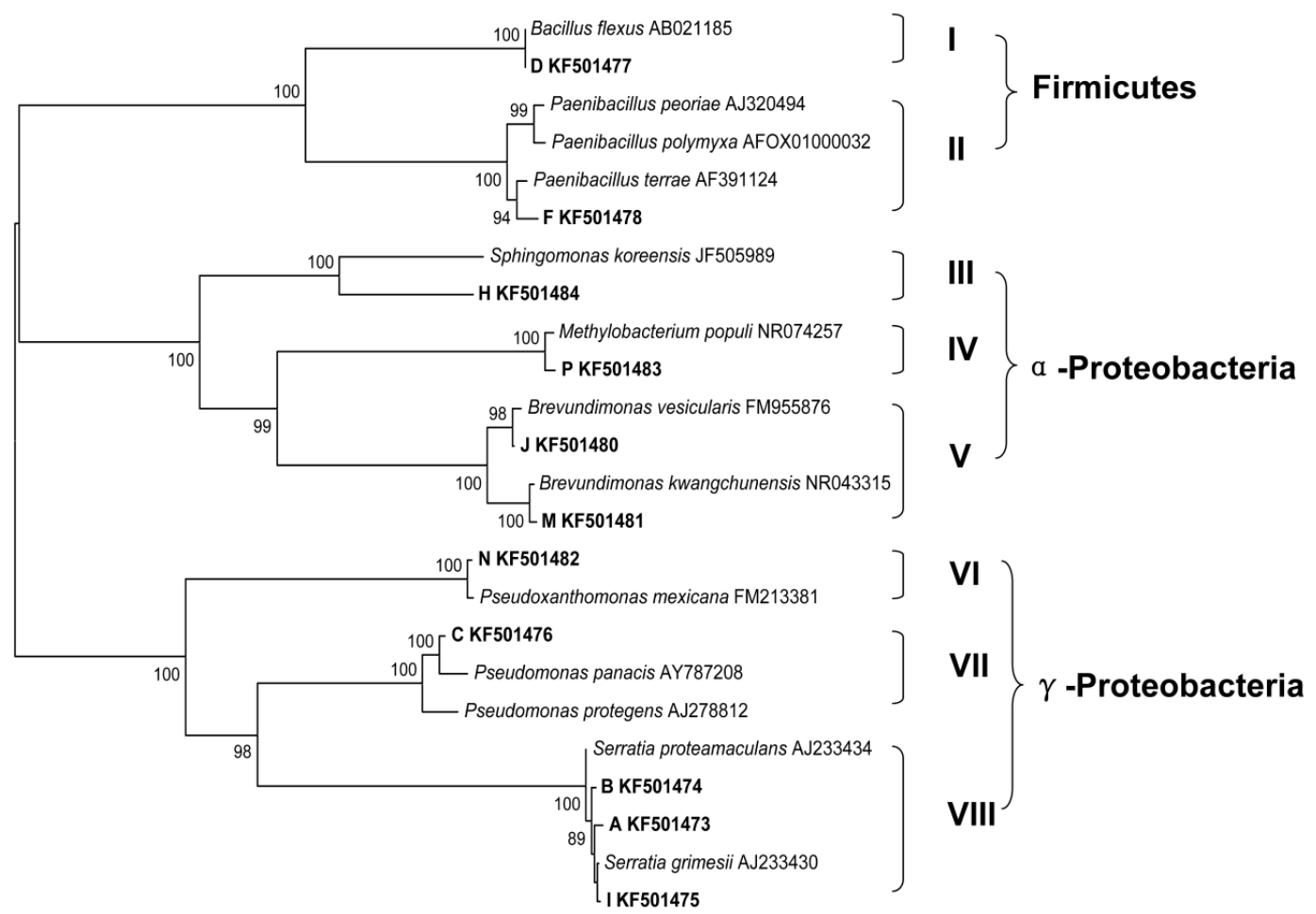


Table 1. Characteristics of cellulose-degrading microorganisms that were separated from guts of D. armandi. +, Positive; -, Negative; $\mathrm{ND}$, no data available; * G, Gram staining.

\begin{tabular}{|c|c|c|c|c|c|c|c|c|c|}
\hline \multirow{2}{*}{$\begin{array}{l}\text { Representative } \\
\text { strains }\end{array}$} & \multirow{2}{*}{ Closest known taxa } & \multirow{2}{*}{ Colony } & \multirow{2}{*}{ Cell morphology } & \multirow{2}{*}{ Pellicle } & \multirow{2}{*}{ Flagella } & \multirow{2}{*}{ Spore } & \multirow{2}{*}{$\mathbf{G} *$} & \multicolumn{2}{|c|}{ Numnero of isolates } \\
\hline & & & & & & & & Medium 2a & Medium $2 b$ \\
\hline $\mathrm{A}$ & Serratia & Pink & Rods, $0.39-0.72 \times 0.92-6.43 \mu \mathrm{m}$ & + & Peritrichous & - & - & 2 & 5 \\
\hline $\mathrm{B}$ & Serratia & Pink & Rods, $0.31-0.66 \times 0.96-5.54 \mu \mathrm{m}$ & + & Peritrichous & - & - & 11 & 20 \\
\hline $\mathrm{C}$ & Pseudomonas & Ivory & Rods, $0.35-0.66 \times 1.08-2.75 \mu \mathrm{m}$ & - & ND & - & - & 10 & 10 \\
\hline $\mathrm{D}$ & Bacillus & Ivory & Rods, $0.38-0.67 \times 0.84-3.24 \mu \mathrm{m}$ & + & Peritrichous & + & + & 2 & 10 \\
\hline $\mathrm{F}$ & Paenibacillus & Pink & Rods, $0.64-1.32 \times 2.12-6.10 \mu \mathrm{m}$ & - & Peritrichous & + & + & 0 & 4 \\
\hline $\mathrm{H}$ & Sphingomonas & Yellow & Rods, $0.32-0.59 \times 0.98-10.62 \mu \mathrm{m}$ & - & Peritrichous & + & - & 0 & 1 \\
\hline I & Serratia & Pink & Rods, $0.36-0.70 \times 0.91-4.98 \mu \mathrm{m}$ & + & Peritrichous & - & - & 2 & 5 \\
\hline $\mathrm{J}$ & Brevundimonas & Pale yellow & Rods, $0.61-1.13 \times 1.64-3.50 \mu \mathrm{m}$ & - & Peritrichous & + & - & 0 & 2 \\
\hline M & Brevundimonas & Ivory & Rods, $0.28-0.50 \times 1.16-3.40 \mu \mathrm{m}$ & - & Peritrichous & + & - & 2 & 1 \\
\hline $\mathrm{N}$ & Pseudoxanthomonas & Yellow & Rods, $0.21-0.38 \times 1.05-2.50 \mu \mathrm{m}$ & + & Polar & - & - & 1 & 1 \\
\hline $\mathrm{P}$ & Methylobacterium & Pale yellow & Rods, $0.32-0.50 \times 0.89-2.40 \mu \mathrm{m}$ & - & $\begin{array}{l}\text { Polar or } \\
\text { subpolar }\end{array}$ & - & - & 2 & 0 \\
\hline
\end{tabular}


Figure 3. Bacterial groups derived from Dendroctonus armandi 16S rRNA genes $(n=91)$.
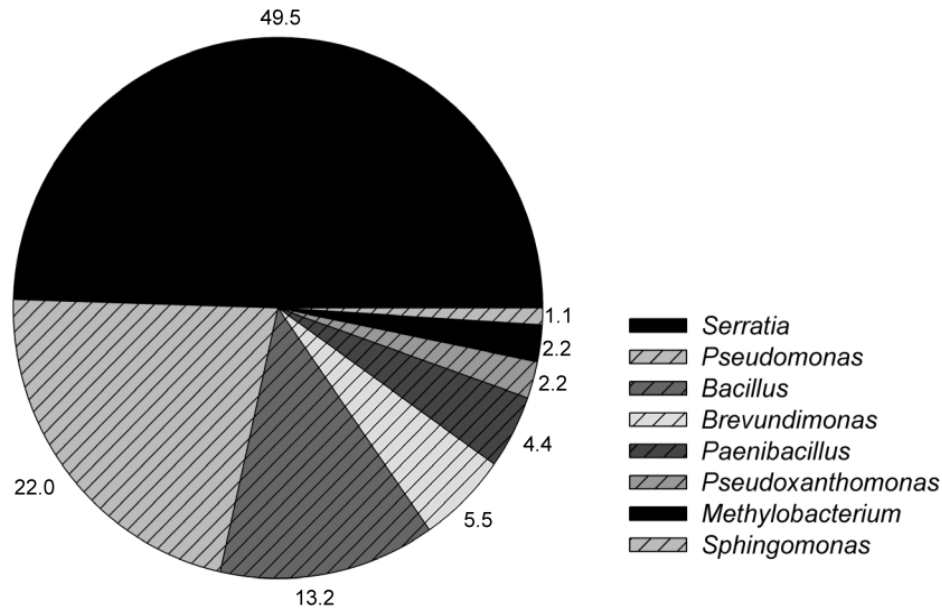

According to distance matrices of the sequences, 8 OTUs $_{0.03}$ clusters were obtained and separately marked as I-VIII. Cluster VIII, which was related to Serratia was the most dominant group in the larval gut according to the results of phylogenetic analysis and morphological identification. Found widespread around the globe, Serratia is a Gram-negative bacterium that is capable of thriving in diverse environments that include water, soil and the digestive tracts of various animals [23]. Serratia spp. have been previously isolated or detected in Dendroctonus spp. [10,24,25]. Known for the ability to produce a myriad of extracellular enzymes such as cellulases [26], Serratia spp. can help the host wood-feeding insect to digest its food better. In addition, the impact of Serratia species on other organisms ranged from parasitic to symbiotic, and these bacteria have in common the ability to resist attack, respond appropriately to environmental conditions and outcompete other microorganisms when colonizing their respective niches [23]. Above all, Serratia was widespread, competitive and closely related to its host insect, resulting in the high abundance of Serratia spp.

Pseudomonas was the second-most dominant group of the cellulolytic bacterial community in the gut of $D$. armandi larvae. The dominance of Pseudomonas was also present in other Coleoptera insect larvae [4]. Bacteria of the genus Pseudomonas can be found in many different environments, including plant, animal tissue, water and soil, and they have the ability to metabolize a variety of nutrients [27]. Many Pseudomonas species are opportunistic pathogens that infect humans, animals and plants [28-30], but some Pseudomonas species have been reported to degrade cellulose [31,32].

Bacillus was the third-most dominant group of the cellulolytic bacterial community in the gut of D. armandi larvae. The cellulolytic activity of Bacillus flexus had been well described [33].

The cellulolytic activities of the other bacterial groups that were found in this study have also been reported previously. The cellulolytic activity of Paenibacillus was reported [34], and Okeke and Lu reported that Pseudoxanthomonas produced an array of cellulolytic-xylanolytic enzymes (filter paper cellulase, $\beta$-glucosidase, xylanase and $\beta$-xylosidase) and also assayed these activities [35]. Methylobacterium expressing $\beta$-1,4-endoglucanase was described [36], and an uncultured cellulolytic strain that is closely related to Sphingomonas was also found in the gut of the termite Zootermopsis angusticollis (Hagen) [37].

To the best of our knowledge, this is the first report describing Brevundimonas kwangchunensis, Brevundimonas vesicularis, Methylobacterium populi and Pseudoxanthomonas mexicana as being 
cellulolytic. The ratio of the $\mathrm{CMC}$ clearance zone diameter to the colony diameter ranged from 4.1 to 5.2 for B. kwangchunensis, indicating robust CMCase production. These cellulolytic bacterial isolates exhibited great potential for the study of novel enzymes in cellulose degradation and for improving the bioconversion of lignocellulosic biomass. Cellulolytic bacteria have also been isolated from the larval gut of the bark beetles Ips pini and Dendroctonus frontalis [9]. All isolates were active against carboxymethylcellulose; nevertheless, only a $S$. vestita isolate showed activity against filter paper. A study of the bacterial flora in the guts of Dendroctonus rhizophagus proposed that most of the bacterial genera that were present could be implicated in nitrogen fixation and cellulose breakdown, which are important roles associated with insect development and fitness, particularly given the challenging environment that is inhabited by bark beetles [10]. All of these results indicate that the bacteria in beetle hindguts play an important role in the degradation of plants and other organic matters that are consumed by $D$. armandi larvae.

\section{Conclusions}

This study investigated the structure of the gut-associated, cellulolytic bacterial communities in D. armandi larvae that were collected from the southern slope of the middle Qinling Mountains in August 2012. Using direct dilution, 11 cellulolytic bacterial stains were identified to be of one genotype that was related to genus Serratia. Additionally, seven genera with varied cellulolytic activities were observed after enrichment. Moreover, some bacterial species were reported to be cellulolytic for the first time in this study, which demonstrates that the bark beetle gut has a great potential to be a source of novel cellulolytic microorganisms.

\section{Acknowledgments}

We acknowledge the financial support of the National Natural Science Foundation of China (31170607, 31170567), Program for Changjiang Scholars and Innovative Research Team in University (IRT1035).

\section{Author Contributions}

Conceived and designed the experiments: Xia $\mathrm{Hu}$, Jiamin $\mathrm{Yu}$, Hui Chen, Chunyan Wang. Performed the experiments: Xia Hu, Jiamin Yu. Analyzed the data: Xia Hu, Jiamin Yu, Chunyan Wang. Contributed reagents/materials/analysis tools: Xia Hu. Wrote the paper: Xia Hu, Chunyan Wang.

\section{Conflicts of Interest}

The authors declare no conflict of interest.

\section{References}

1. Purves, C.B. Chemical Nature of Cellulose and its Derivatives. In Cellulose and Cellulose Derivatives, Part 1; Spurlin, H.M., Grafflin, M.W., Eds.; Interscience: New York, NY, USA, 1954; pp. 29-98. 
2. Ghio, S.; di Lorenzo, G.S.; Lia, V.; Talia, P.; Cataldi, A.; Grasso, D.; Campos, E. Isolation of Paenibacillus sp. and Variovorax sp. Strains from decaying woods and characterization of their potential for cellulose deconstruction. Int. J. Biochem. Mol. Biol. 2012, 3, 352-364.

3. Sun, J.Z.; Scharf, M. Exploring and integrating cellulolytic systems of insects to advance biofuel technology. Insect Sci. 2010, 17, 163-165.

4. Huang, S.; Sheng, P.; Zhang, H. Isolation and identification of cellulolytic bacteria from the gut of Holotrichia parallela larvae (coleoptera: Scarabaeidae). Int. J. Mol. Sci. 2012, 13, 2563-2577.

5. Ni, J.; Tokuda, G. Lignocellulose-degrading enzymes from termites and their symbiotic microbiota. Biotechnol. Adv. 2013, 31, 838-850.

6. Haack, R.A.; Slansky, F., Jr. Nutritional Ecology of Wood-Feeding Coleoptera, Lepidoptera, and Hymenoptera. In Nutritional Ecology of Insects, Mites, Spiders, and Related Invertebrates; Slansky, F., Jr., Rodriguez, J., Eds.; Wiley: New York, NY, USA, 1987; pp. 449-486.

7. Coulson, R.; Stark, R. Integrated management of bark beetles. In Bark Beetles in North American Conifers: A System for the Study of Evolutionary Biology; Mitton, J.B., Sturgeon, K.B., Eds.; University of Texas Press: Austin, TX, USA, 1982; pp. 315-349.

8. Chen, H.; Tang, M.; Liu, L.; Wang, H.; Li, Z. Cytochemical localization of acid phosphatase activity in tissues of Pinus armandi infected by Leptographium qinlingensis. Symbiosis (Rehovot) 2007, 43, 65-70.

9. Delalibera, I.; Handelsman, J., Jr.; Raffa, K.F. Contrasts in cellulolytic activities of gut microorganisms between the wood borer, Saperda vestita (coleoptera: Cerambycidae), and the bark beetles, Ips pini and Dendroctonus frontalis (coleoptera: Curculionidae). Environ. Entomol. 2005, 34, 541-547.

10. Morales-Jiménez, J.; Zúñiga, G.; Ramírez-Saad, H.C.; Hernández-Rodríguez, C. Gut-associated bacteria throughout the life cycle of the bark beetle Dendroctonus rhizophagus Thomas and Bright (Curculionidae: Scolytinae) and their cellulolytic activities. Microb. Ecol. 2012, 64, 268-278.

11. Hu, X.; Wang, C.; Chen, H.; Ma, J. Differences in the structure of the gut bacteria communities in development stages of the Chinese white pine beetle (Dendroctonus armandi). Int. J. Mol. Sci. 2013, 14, 21006-21020.

12. Teather, R.M.; Wood, P.J. Use of congo red-polysaccharide interactions in enumeration and characterization of cellulolytic bacteria from the bovine rumen. Appl. Environ. Microbiol. 1982, $43,777-780$.

13. Weisurg, W.G.; Barns, S.M.; Pelletier, D.A.; Lane, D.J. 16S ribosomal DNA amplification for phylogenetic study. J. Bacteriol. 1991, 173, 697-703.

14. Martínez-Murcia, A.; Acinas, S.; Rodriguez-Valera, F. Evaluation of prokaryotic diversity by restrictase digestion of $16 \mathrm{~S}$ rDNA directly amplified from hypersaline environments. FEMS Microbiol. Ecol. 1995, 17, 247-255.

15. Cole, J.R.; Wang, Q.; Cardenas, E.; Fish, J.; Chai, B.; Farris, R.J.; Kulam-Syed-Mohideen, A.S.; McGarrell, D.M.; Marsh, T.; Garrity, G.M.; et al. The ribosomal database project: Improved alignments and new tools for rRNA analysis. Nucleic Acids Res. 2009, 37, D141-D145.

16. Wheeler, D.L.; Barrett, T.; Benson, D.A.; Bryant, S.H.; Canese, K.; Chetvernin, V.; Church, D.M.; DiCuccio, M.; Edgar, R.; Federhen, S.; et al. Database resources of the national center for biotechnology information. Nucleic Acids Res. 2007, 35, D5-D12. 
17. Edgar, R.C. Muscle: Multiple sequence alignment with high accuracy and high throughput. Nucleic Acids Res. 2004, 32, 1792-1797.

18. Tamura, K.; Peterson, D.; Peterson, N.; Stecher, G.; Nei, M.; Kumar, S. Mega5: Molecular evolutionary genetics analysis using maximum likelihood, evolutionary distance, and maximum parsimony methods. Mol. Biol. Evol. 2011, 28, 2731-2739.

19. Schloss, P.D.; Handelsman, J. Introducing DOTUR, a computer program for defining operational taxonomic units and estimating species richness. Appl. Environ. Microbiol. 2005, 71, 1501-1506.

20. Gregersen, T. Rapid method for distinction of gram-negative from gram-positive bacteria. Eur. J. Appl. Microbiol. Biotechnol. 1978, 5, 123-127.

21. Smibert, R. Phenotypic Characterization. In Methods for General and Molecular Bacteriology; Murray, R.G.E., Wood, W.A., Eds; American Society for Microbiology: Washington, DC, USA, 1994.

22. Cazemier, A.E.; Verdoes, J.C.; Reubsaet, F.A.; Hackstein, J.H.; van der Drift, C.; den Camp, H.J.O. Promicromonospora pachnodae sp. nov., a member of the (hemi) cellulolytic hindgut flora of larvae of the scarab beetle Pachnoda marginata. Anton. Leeuw. Int. J. G. 2003, $83,135-148$.

23. Petersen, L.M.; Tisa, L.S.S. Friend or foe? A review of the mechanisms that drive Serratia towards diverse lifestyles. Can. J. Microbiol. 2013, 59, 627-640.

24. Yilmaz, H.; Sezen, K.; Kati, H.; Demirbað, Z. The first study on the bacterial flora of the European spruce bark beetle, Dendroctonus micans (Coleoptera: Scolytidae). Biologia 2006, 61, 679-686.

25. Vasanthakumar, A.; Delalibera, I.; Handelsman, J.; Klepzig, K.D.; Schloss, P.D.; Raffa, K.F. Characterization of gut-associated bacteria in larvae and adults of the southern pine beetle, Dendroctonus frontalis Zimmermann. Environ. Entomol. 2006, 35, 1710-1717.

26. Anand, A.A.P.; Vennison, S.J.; Sankar, S.G.; Prabhu, D.I.G.; Vasan, P.T.; Raghuraman, T.; Geoffrey, C.G.; Vendan, S.E. Isolation and characterization of bacteria from the gut of Bombyx mori that degrade cellulose, xylan, pectin and starch and their impact on digestion. J. Insect Sci. 2010, 10, doi:10.1673/031.010.10701.

27. Palleroni, N.J. The Pseudomonas story. Environ. Microbiol. 2010, 12, 1377-1383.

28. Brodey, C.L.; Rainey, P.B.; Tester, M.; Johnstone, K. Bacterial blotch disease of the cultivated mushroom is caused by an ion channel forming lipodepsipeptide toxin. Mol. Plant-Microbe Interact. 1991, 4, 407-411.

29. Young, J. Drippy gill: A bacterial disease of cultivated mushrooms caused by Pseudomonas agaricin sp. N. Z. J. Agric. Res. 1970, 13, 977-990.

30. Kodama, K.; Kimura, N.; Komagata, K. Two new species of pseudomonas: P. Oryzihabitans isolated from rice paddy and clinical specimens and $P$. Luteola isolated from clinical specimens. Int. J. Syst. Evol. Microbiol. 1985, 35, 467-474.

31. Meyers, M.; Poffe, R.; Verachtert, H. Properties of a cellulolytic pseudomonas. Antonie van Leeuwenhoek 1984, 50, 301-301.

32. Sindhu, S.; Dadarwal, K. Chitinolytic and cellulolytic Pseudomonas sp. Antagonistic to fungal pathogens enhances nodulation by Mesorhizobium sp. Cicer in chickpea. Microbiol. Res. 2001, $156,353-358$. 
33. Trivedi, N.; Gupta, V.; Kumar, M.; Kumari, P.; Reddy, C.; Jha, B. An alkali-halotolerant cellulase from Bacillus flexus isolated from green seaweed Ulva lactuca. Carbohydr. Polym. 2011, 83, 891-897.

34. Yang, J.K.; Zhang, J.J.; Yu, H.Y.; Cheng, J.W.; Miao, L.H. Community composition and cellulase activity of cellulolytic bacteria from forest soils planted with broad-leaved deciduous and evergreen trees. Appl. Microbiol. Biotechnol. 2013, doi:10.1007/s00253-013-5130-4.

35. Okeke, B.C.; Lu, J. Characterization of a defined cellulolytic and xylanolytic bacterial consortium for bioprocessing of cellulose and hemicelluloses. Appl. Biochem. Biotechnol. 2011, 163, 869-881.

36. Ferreira Filho, A.S.; Quecine, M.C.; Bogas, A.C.; de Barros Rossetto, P.; de Souza Lima, A.O.; Lacava, P.T.; Azevedo, J.L.; Araújo, W.L. Endophytic methylobacterium extorquens expresses a heterologous â-1,4-endoglucanase A (EglA) in Catharanthus roseus seedlings, a model host plant for xylella fastidiosa. World J. Microbiol. Biotechnol. 2012, 28, 1475-1481.

37. Wenzel, M.; Schönig, I.; Berchtold, M.; Kämpfer, P.; König, H. Aerobic and facultatively anaerobic cellulolytic bacteria from the gut of the termite Zootermopsis angusticollis. J. Appl. Microbiol. 2002, 92, 32-40.

(C) 2014 by the authors; licensee MDPI, Basel, Switzerland. This article is an open access article distributed under the terms and conditions of the Creative Commons Attribution license (http://creativecommons.org/licenses/by/3.0/). 